\title{
Detection of Spodoptera frugiperda (J.E. Smith) (Lepidoptera: Noctuidae) in maize field in East Flores District, East Nusa Tenggara Province, Indonesia
}

\author{
LINCE MUKKUN", YASINTA LETEK KLEDEN, AGNES VIRGINIA SIMAMORA \\ Department of Agrotechnology, Faculty of Agriculture, Universitas Nusa Cendana. Jl. Adi Sucipto, Penfui, Kupang 85001, East Nusa Tenggara, \\ Indonesia. Tel... +62-8133911212, `email: 1mukkun@gmail.com
}

Manuscript received: 7 March 2021. Revision accepted: 4 May 2021

\begin{abstract}
Mukkun L, Kleden YL, Simamora AV. 2021. Detection of Spodoptera frugiperda (J.E. Smith) (Lepidoptera: Noctuidae) in maize field in East Flores District, East Nusa Tenggara Province, Indonesia. Intl J Trop Drylands 5: 20-26. Fall armyworm (FAW), Spodoptera frugiperda (J.E. Smith), is a pest originating from America and rapidly spread to various parts of the world, including Indonesia. In January 2020, armyworm attacks appeared on maize plantations in several districts in East Nusa Tenggara Province, Indonesia one of which is in East Flores District. This study aimed to identify $S$. frugiperda occurrence in East Flores District and to determine the damage intensity of $S$. frugiperda and the population of larvae on the maize plant. The maize fields were surveyed, and purposive sampling technique was used to assess the maize plants damaged by armyworm. Observations were made on the symptoms of the damage, identification of armyworm species, percentage of attacked corn plants, the intensity of the infestation, and maize cultivars planted by farmers. The results showed that $S$. frugiperda caused severe damage of 85 to $100 \%$ of the cultivated maize plants with damage intensity on a scale of 6 to 9 . The larval population was relatively high, ranging from 1 to 28 per plant with an average of 6.65 in West Solor Subdistrict, while in Ile Mandiri Subdistrict, it ranged from 1 to 7 larvae per plant with an average of 2.55 per plant on heads.
\end{abstract}

Keywords: Control, fall armyworm, identification, monitoring, pesticides, Spodoptera frugiperda

\section{INTRODUCTION}

Fall Armyworm (FAW), Spodoptera frugiperda (J.E. Smith), is a pest originating from America, but it is rapidly widespread to various parts globally. In January 2016, FAW was first discovered in West Africa (Nigeria and Ghana) and spread to almost all sub-Saharan Africa countries (Brévault et al. 2018). In May 2018, FAW was discovered in Karnataka in southwest India, and by late 2018 FAW outbreaks had been found in additional southeastern Asia countries, such as Bangladesh, Myanmar, and Thailand (Sun et al. 2019). S. frugiperda is a transboundary destructive pest that will continue to spread because it has unique biological characteristics supported by the high volume of trade in goods between countries.

This pest attacks the plant's growing points, making plant failing to form shoot/young leaves. Fall armyworm larvae are reported to attack more than 80 plant species, including maize, rice, sorghum, barley, sugarcane, vegetables, and cotton. FAW larvae can damage almost all parts of corn plants (roots, leaves, male flowers, female flowers, and cobs) (Nonci et al., 2019). According to Assefa \& Ayalew (2019), armyworms that attack maize in the mid and late stages of corn growth can cause yield losses ranging from 15 to $73 \%$, with a range of the number of plants affected by $55-100 \%$. The reported losses vary depending on the age of the maize affected, the variety, and cultivation techniques used. Due to this pest attack on maize crops in Africa, the losses incurred are between 8.3 and 20.6 million tons per year, with an economic loss value of between US \$ 2.5-6.2 billion per year (FAO \& CABI 2019).

Because of its wide range of hosts, S. frugiperda is one of the most destructive pests threatening annual crops in tropical regions (da Silva et al. 2017). S. frugiperda needs to be controlled because of its invasive nature with a short life cycle, i.e. adult female insects can produce 900-1200 eggs; thus, the population increases rapidly and threatens cultivated plants in the tropics. Control with insecticides is reported to be less effective, and in Africa, it is reported that armyworm has been increasingly resistant to many groups of insecticides (Subiono 2020; Gutirrez-Moreno et al. 2019; Prasanna et al. 2018)

In early 2019 , this pest was found in Indonesia, i.e. in maize plants in West Pasaman District, West Sumatra (Maharani et al. 2019). FAW was reported to have damaged maize crops with a high-intensity attack rate, and larvae population was between 2-10 per plant. In Lampung, this pest attack on maize has also been reported. It has also been reported that in June 2019, FAW was identified in maize plantations in Bandung District (Soreang), Garut District (Leles, Banyuresmi, and Sucinaraja), and in Sumedang District (Jatinangor) with low to high populations (Maharani et al., 2019). In January 2020, an armyworm attack appeared on maize plantations in several districts in East Nusa Tenggara Province, one of which is in East Flores District. The area of the maize crop attacked was 4,585 ha out of a total planted area of 12,072 ha spread 
over 19 sub-districts (Data from The Ofice of Agriculture and Food Security, East Flores District). However, there has been no scientific study of the species and levels of the attack on maize crops in East Flores. Therefore, it is necessary to do early detection to identify pest species, determine the level of attack, and develop appropriate control strategies both in the short and long term. This study aims to identify $S$. frugiperda attack in East Flores District, determine the intensity of pest attacks, and determine the larval population that attacks maize.

\section{MATERIALS AND METHODS}

\section{Study area and period}

This research was carried out at the maize plantations that have been attacked by armyworms, including in the West Solor Sub-district and Ile Mandiri Sub-district, East Flores District, East Nusa Tenggara Province, Indonesia, in February 2020.

\section{Research methods}

The research was conducted using a survey method, including interview techniques and direct observation. Interviews were conducted with officers from the Office of Agriculture and Food Security, East Flores District, to determine the location and whereabouts of maize plantations that were attacked by $S$. frugiperda, as well as maize farmers. Direct observations were made on pests' morphology, including egg, larvae, pupae, and imago, to identify the species of armyworm, attack symptoms, attack intensity, and the percentage of plants affected. Determination of the sampling location was carried out purposively in villages and gardens that armyworm pests had attacked.

\section{Sampling}

Each planting area was sampled by taking 200 maize plants which were determined systematically. A sampling of larvae was carried out directly using a soft brush or tweezers on maize plants that showed signs of damage. The samples taken were larvae of the Lepidoptera group. The samples obtained were put into a plastic bag to be identified, and the morphological data of insects were obtained in a new state. The plastic bags were labeled containing location name, date of collection, and varieties of corn. The samples obtained were identified morphologically at the Plant Pest Laboratory, Faculty of Agriculture, Nusa Cendana University.

\section{Observation}

Morphological data, including shape, color, the pattern of the head, the shape of the spines on the body, and the number of pinacula, were recorded visually. Sampling 100 plants was conducted to determine the number of larvae per plant. The leaf whorl of plants showing signs of an attack was opened, and the number of larvae per plant was counted. The percentage of damaged plants was estimated by counting the number of clumps of plants showing symptoms of an attack on 100 sample clumps of plants.
The damage intensity was carried out using a scoring system of 1 to 9 (Table 1) (FAO and CABI, 2019). Data on temperature, humidity, and daily rainfall were sourced from the Kupang Meteorological, Climatology, and Geophysical Agency as secondary data.

\section{Data analysis}

The data collected were qualitative and quantitative, subsequently tabulated and analyzed. Symptoms of damage were described in narrative form and pictures. Meanwhile, the number of larvae per clump, the percentage of crop damage, and the damage intensity were analyzed and presented in tables and graphs.

Table 1. Scale of attack of armyworms on leaves

\begin{tabular}{|c|c|}
\hline Scale & Damage definitions \\
\hline 0 & No damage \\
\hline 1 & A speck of the borehole \\
\hline 2 & $\begin{array}{l}\text { Several points of holes and circles of small holes on the } \\
\text { leaves }\end{array}$ \\
\hline 3 & $\begin{array}{l}\text { Small holes, small circular lesions, multiple lesions } \\
\text { extending to more than } 1.3 \mathrm{~cm} \text { across the entire leaf } \\
\text { surface }\end{array}$ \\
\hline 4 & $\begin{array}{l}\text { Some of the lesions extend about } 1.3 \text { to } 2 \mathrm{~cm} \text { across the } \\
\text { leaf surface }\end{array}$ \\
\hline 5 & $\begin{array}{l}\text { Some lesions display more than } 2.5 \mathrm{~cm} \text { in size on some } \\
\text { leaves, and/or several holes are small to medium in size, } \\
\text { with a uniform or irregular shape due to consumption by } \\
\text { caterpillars }\end{array}$ \\
\hline 6 & $\begin{array}{l}\text { Multiple large elongated lesions on several leaflets with } \\
\text { no size }\end{array}$ \\
\hline 7 & $\begin{array}{l}\text { Many large elongated lesions on several leaves of } \\
\text { irregular or irregular shape }\end{array}$ \\
\hline 8 & $\begin{array}{l}\text { Many lesions on almost all leaf surfaces with large holes } \\
\text { because some of the leaf surface is eaten by caterpillars }\end{array}$ \\
\hline 9 & Almost all the leaves are damaged/destroyed \\
\hline
\end{tabular}

\section{RESULTS AND DISCUSSION}

\section{Distribution and extent of $S$. frugiperda infestation}

Based on data from the Office of Agriculture and Food Security of East Flores District (Table 2) showed that $S$. frugiperda had attacked maize plantations in 18 of the 19 sub-districts. Of the total planted area of 12072 ha in 2020, about 4,585 ha $(37.98 \%)$ of the total area was affected. The armyworms infestation was also not evenly distributed across sub-district (Figure 1).

The incidence of $S$. frugiperda was recorded in almost all sub-districts after 3-4 weeks of maize planting. Several sub-districts experienced severe damage to maize crops, including West Solor (100\%), Titehena (95\%), Waiotan Ulumado (92.75\%), Ile Bura (82.56\%), East Adonara (70.16\%), and Tanjung Bunga $(52.07 \%)$. S. frugiperda is reported as a highly destructive pest, which can fly hundreds of kilometers overnight with the help of wind (Bagariang 2019; Westbrook et al. 2016). In addition, these pests can also be carried through seeds and also with the help of human transportation inadvertently (Sisay et al. 2019). The existence of a certain type of pest is strongly 
influenced by ecological factors, especially insects that cause damage to crops (Baskauf 2003) such as $S$. frugiperda. The laboratory studies in Ghana reported that one life cycle of $S$. frugiperda could be completed for 30 days at $25^{\circ} \mathrm{C}$; in one year, 12 generations are produced (Nboyine et al. 2020). Tropical climatic conditions and their polyphagous nature can cause an exponential increase in population over a period of time (Harrison et al. 2019; Du Plessis et al. 2020). Control measures against the $S$. frugiperda pest are carried out chemically by spraying with various types of insecticides. However, the control is not comprehensive and is applied only during severe attacks to not suppress the pest population.

\section{Spodoptera frugiperda identification}

Identification of the $S$. frugiperda was carried out by using morphological characters which differentiate it from other species.

\section{Larva}

There are distinct four characteristics of S. frugiperda larvae that are not shared by other species, such as (1) the presence of an inverted Y letter on the head (Figure 2A), (2) 4 points (pinacula) forming a rectangle on the abdomen of the segment 8 (Figure 2B), (3) a thick line like a ribbon on the lateral part of the body, and (4) a pinacula with a single seta (Jeger et al. 2017; Jacobs et al. 2018).

The larvae characteristics observed in the present study are the same as the morphological descriptions of $S$. frugiperda larvae (Ganiger et al. 2018; Bagariang 2019). The larvae found at the time of observation varied in number and size. One to 10 larvae were found in each maize clump, with larval stages varying from 1 to 6 instar larvae. This indicates that there have been overlapping generations of the pest that has developed more than one life cycle. Generally, 3 to 6 larvae were found in feeding on leaf whorl and damaging the growing point by scrapping the young leaves and boring the stems. If the leaflets that are still rolled are opened, medium to large larvae was found, while younger larvae found scrapping on the leaf surface (Figure 3).

Table 2. Infestation of Spodoptera frugiperda on maize field in East Flores District, East Nusa Tenggara Province

\begin{tabular}{llll}
\hline \multicolumn{1}{c}{ Sub-district } & $\begin{array}{l}\text { Planted } \\
\text { area (ha) }\end{array}$ & $\begin{array}{l}\text { Damaged } \\
\text { area (ha) }\end{array}$ & \multicolumn{1}{c}{ Insecticide used } \\
\hline Adonara Timur & 124 & 87 & Decis \\
Ile Boleng & 1246 & 102 & Decis, Siklon \\
Witihama & 2009 & 540 & Foker \\
Adonara & 250 & 22 & Sidametrin, Buldox \\
Waiotan & 193 & 179 & $\begin{array}{l}\text { Sidametrin, Arivo, } \\
\text { Super Max, Decis }\end{array}$ \\
Ulumado & & & Sidametrin, Arivo, Decis \\
Tanjung bunga & 916 & 477 & Decis, Panser \\
Larantuka & 172 & 84 & Decis \\
Ile Mandiri & 603 & 201 & Decis, Arivo, Amabas \\
Demon Pagong & 119 & 32 & Arivo, Supermax, \\
Lewolema & 305 & 61 & Baycarb, Decis \\
& & & Decis, Siklon \\
Titehena & 640 & 608 & Foker \\
Wulanggitang & 999 & 50 & Arivo, Panser \\
Ile Bura & 585 & 483 & Sidametrin, Arivo, Decis \\
Solor Barat & 1012 & 1012 & Arivo, Amabas, Decis \\
Solor Selatan & 971 & 273 & Decis, Sidametrin, Arivo \\
Solor Timur & 1324 & 361 & Cypermax \\
Adonara Barat & 454 & 9 & - \\
Klubagolit & 124 & 40 & - \\
Adonara Tengah & 66 & 0 & \\
Total & 12.072 & 4.585 & \\
\hline
\end{tabular}

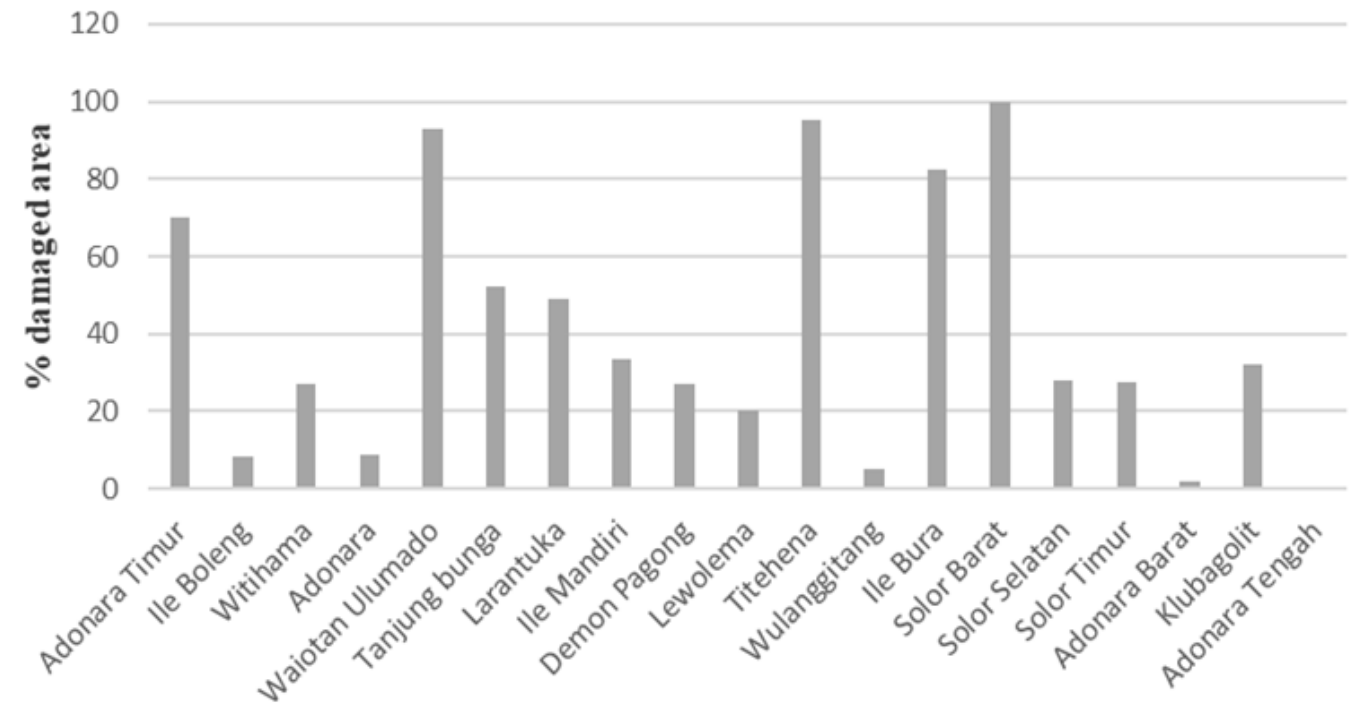

Figure 1. Distribution and percentage of planted areas affected by Spodoptera frugiperda in East Flores District, Indonesia 


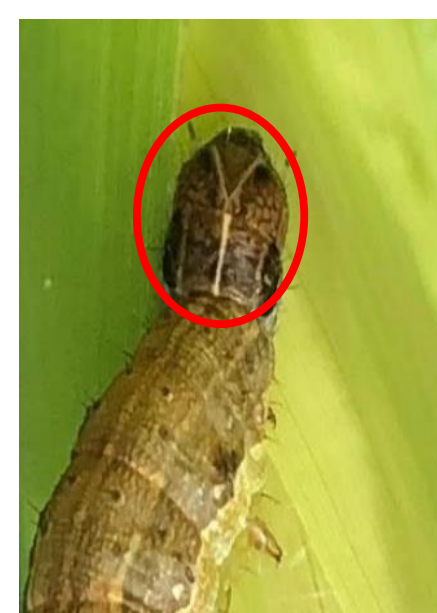

A

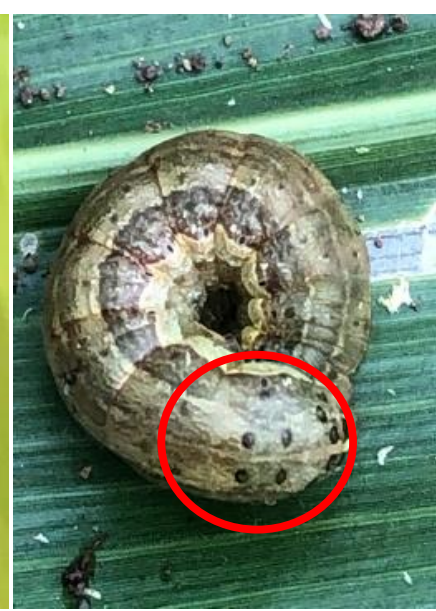

B

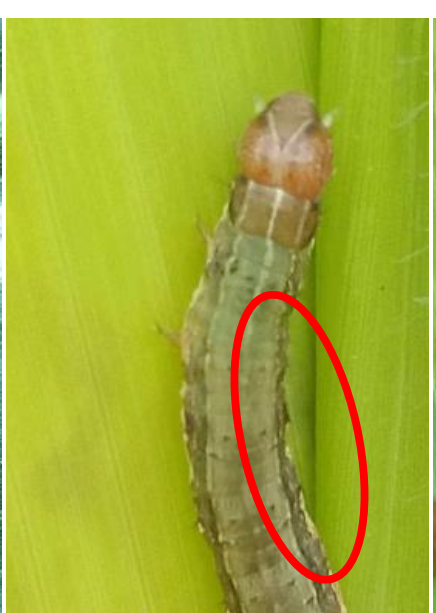

C

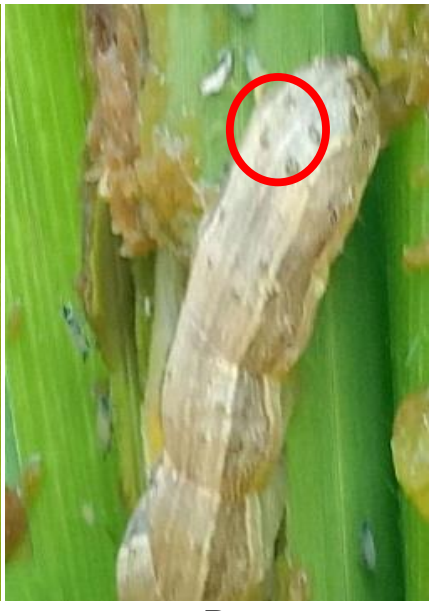

D

Figure 2. A. Inverted Y letter on head, B. 4 rectangular panicula in segment 8 abdomen, C. thick line on the lateral part of the body, D. panicula with a single seta

\section{Damage symptoms}

The attack symptoms of $S$. frugiperda are also very distinctive so that they can be easily distinguished from that of other armyworm species. The frost around the maize leaves indicates a heavy attack of larvae on the leaves caused by the instar larvae (Figure 4). In a mild attack, tiny larvae feed on the leaf bark's surface, making it appear transparent (Figure 4A). In a further attack, the leaves' larvae boreholes to show holes or torn leaves (Figure 4B). Damage to plants is usually marked by frost on the leaf surface and around the shoots after larval feeding (Figure 4 C, D). The initial symptoms of a FAW attack are similar to those of other pests on maize. If the larvae damage shoots, young leaves, or growing points of the plant, they can kill the plant. In African countries, the loss of maize crop due to FAW attacks is between 4 and 8 million tons per year, with a nominal loss of between the US \$ 1-4.6 million per year. In Nicaragua, insecticide application can save yields of about 33\% (Nonci et al. 2019). The reported losses vary depending on the age of the maize affected. In addition, yield losses also depend on the variety and cultivation techniques used.

\section{Imago}

Imago or adult insects were found to have the following characteristics: $S$. frugiperda imago wingspan ranges from 32 to $40 \mathrm{~mm}$. Male imago size is slightly smaller than female imago. On the forewings of $S$. frugiperda male imago, there is a striking whitish mark on the tip and center. Meanwhile, the forewing of female $S$. frugiperda imago is slightly darker than male imago and has a pale complexion, ranging from grayish brown to gray and light brown patches. The hind wings of both sexes of $S$. frugiperda imago are silver-whitish with dark stripes on the edges.

Based on the characteristics of larvae, imago, and attack symptoms compared with the literature (Nboyine et al. 2020; FAO \& CABI, 2019), it can be concluded that the species of armyworm that attacks maize crops in East
Flores District, East Nusa Tenggara Province is Spodoptera frugiperda (JE Smith).

\section{Percentage of affected planting area and plants, damage intensity and number of S. frugiperda larvae per plant}

The percentage of maize area affected, the percentage of plant damage, the damage intensity, and the number of larvae attacking maize in three sub-districts in East Flores District are presented in Table 3. Almost all maize crops in East Flores District have been attacked (on average 80 to $100 \%$ ) by $S$. frugiperda, and 45 to $100 \%$ of the plants were damaged. The damage intensity was ranged from 4 to 8 on a 0 - 9 scale. The damaged lesions on the leaf surface were 1.3 to $2 \mathrm{~cm}$ due to larval feeding, and even in some instances, the whole plant was destroyed by mature larvae. The number of larvae present in each plant determines the severity of this armyworm attack. The invasive armyworm S. frugiperda is a very destructive pest with a high-speed spreading ability. The previous research results showed that this pest could damage and spread ten times higher than other species of armyworm pests (Hruska 2019; Sisay et al. 2019).

Controls of this pest were carried out by spraying insecticides on maize crops, but this method did not show encouraging results due to the higher larval population of $S$. frugiperda. These results were probably due to several things, including (i) incomplete spraying of insecticides due to limited human resources, tools, and insecticides available, (ii) inappropriate insecticides used, (iii) low rainfall; thus, maize plants experience slow growth. Besides, the ability to move quickly causes these pests to move to other fields; therefore, their spread occurs quickly. Hruska (2019) stated that an insecticide application is usually not economical for control of the fall armyworm. However, it may be necessary if the infestation is extremely severe and the plants are under stress.

In Table 4, it can be seen that the intensity of monthly rainfall in East Flores during the rainy season (November 2019 - May 2020) was very low, ranging from 0.04 to 11.4 
$\mathrm{mm}$. Meanwhile, the humidity $(\mathrm{RH})$ was high, especially when the farmers started planting maize, ranging from 76.74 to $84.54 \%$. The average temperature was also in the range of $27^{\circ} \mathrm{C}$ to $30^{\circ} \mathrm{C}$ and is the optimum temperature range for developing this insect pest. Nurzannah et al. (2020) demonstrated that the optimum temperature for larval development is $28^{\circ} \mathrm{C}$, while the pupa and imago require lower temperatures. Larvae are the destructive stage of the $S$. frugiperda pest, with a high larval development rate, the intensity of the damage caused can also be high. The optimum temperature will also affect the pest population because in a short time (less than 30 days), a new generation will be formed. In a year, it will produce a minimum of 12 generations if the host is available (Du Plessis et al. 2020).

Low rainfall conditions also increase the ability to develop shorter reproductive cycles and higher distribution capabilities of $S$. frugiperda. However, if the rainfall increases, the pest population decreases due to pests being washed or carried away by rainwater, and plant development improves (Nurzannah et al. 2020; JaramilloBarrios et al. 2019).

Table 3. Average percentage of planting area and maize plants affected, intensity of damage and number of Spodoptera frugiperda larvae in maize in East Flores District, Indonesia

\begin{tabular}{llcccc}
\hline Sub-district & Village & $\begin{array}{c}\% \\
\text { infected } \\
\text { field }\end{array}$ & $\begin{array}{c}\% \\
\text { infected } \\
\text { plant }\end{array}$ & $\begin{array}{c}\text { Scale of } \\
\text { attack on } \\
\text { leaves } \\
\text { (1-9) }\end{array}$ & $\begin{array}{c}\text { Number } \\
\text { of larvae/ } \\
\text { plant }\end{array}$ \\
\hline West Solor & Kalelu & 100 & 100 & 8 & 6.60 \\
& Ritaebang & 85 & 68 & 6 & 6.45 \\
Ile Mandiri & Riangkemie & 100 & 50 & 5 & 2.40 \\
& Lewohala & 80 & 45 & 4 & 2.20 \\
Tanjung Bunga & Waiklibang & 85 & 85 & 8 & 5.20 \\
& Kolaka & 65 & 50 & 6 & 3.55 \\
\hline
\end{tabular}

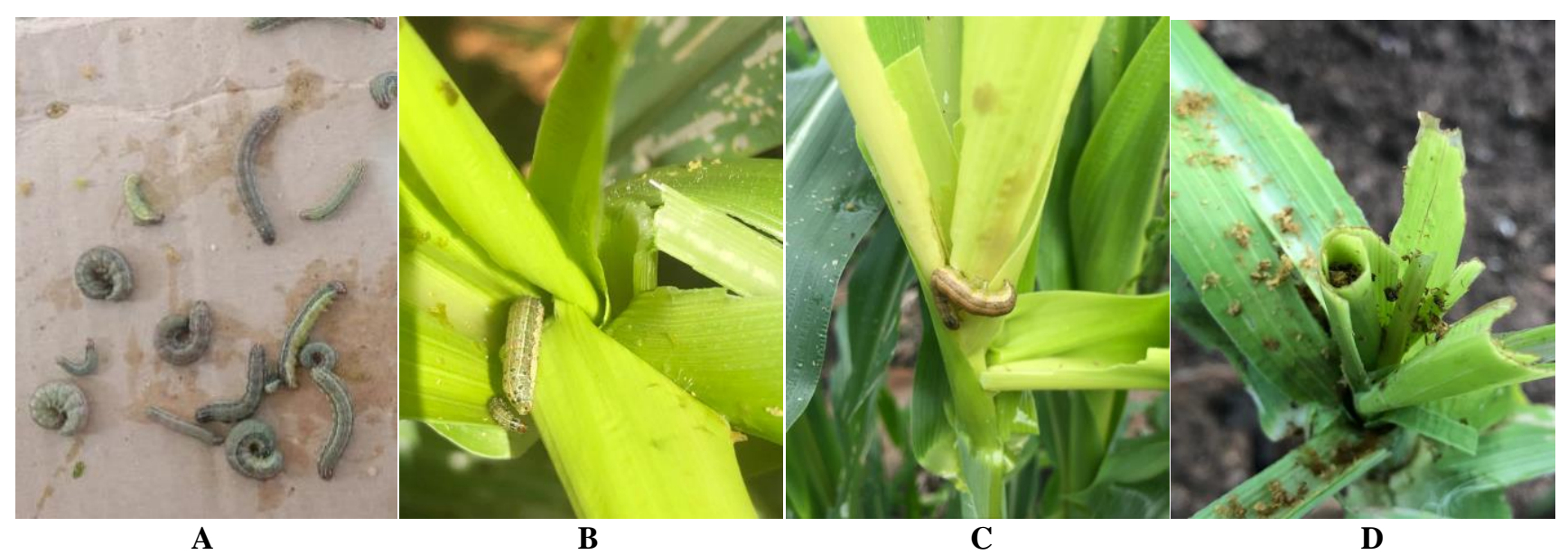

Figure 3. A. Larvae of various sizes (instar), B. Instar 3 and 5 larvae in one maize clump, C. Third instar larvae, D. Affected maize plants

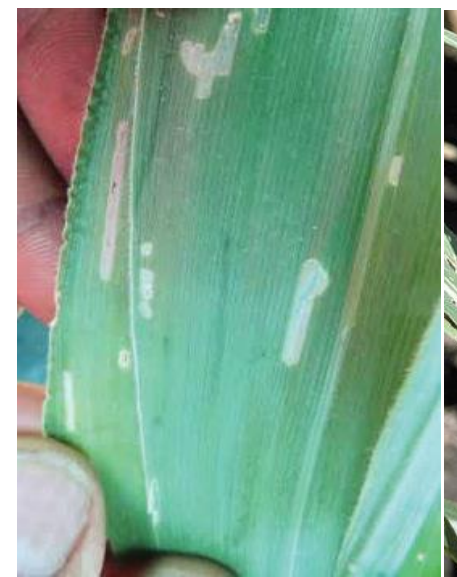

A

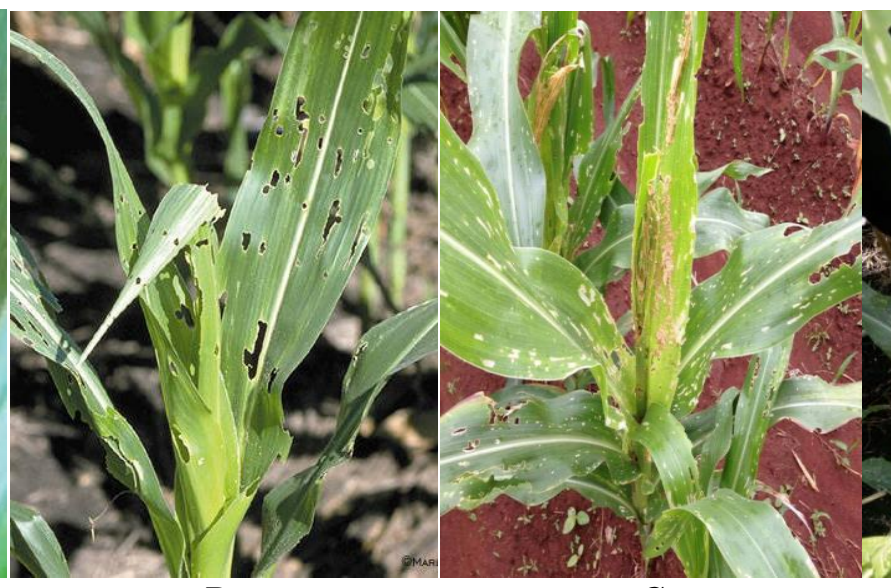

B
C

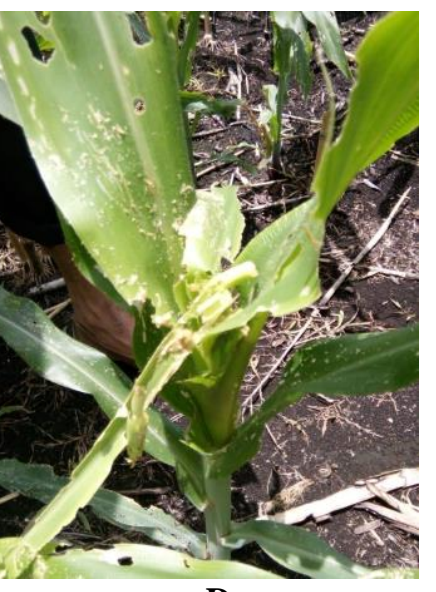

D

Figure 4. Symptoms of attack on maize leaves, A. Small spots caused by early instar larvae, B. More leaf holes, caused by 3-4 instar larvae, C. Almost all leaves are damaged, D. Damaged plants to the point of growing 
Table 4. Average temperature, humidity and monthly rainfall in East Flores District, Indonesia

\begin{tabular}{lccl}
\hline \multicolumn{1}{c}{ Month/year } & $\begin{array}{c}\text { Temperature } \\
\left({ }^{\mathbf{0}} \mathbf{C}\right)\end{array}$ & $\begin{array}{c}\text { RH } \\
(\mathbf{\%})\end{array}$ & $\begin{array}{c}\text { Rainfall } \\
(\mathbf{m m})\end{array}$ \\
\hline October/2019 & 29.24 & 71.93 & 0 \\
November/2019 & 30.30 & 69.86 & 0.04 \\
December/2019 & 29.84 & 76.74 & 2.58 \\
January/2020 & 27.93 & 84.54 & 11.14 \\
February/2020 & 28.75 & 81.81 & 8.23 \\
March/2020 & 28.26 & 82.65 & 5.52 \\
April/2020 & 28.56 & 79.03 & 4.61 \\
May/2020 & 28.54 & 77.77 & 7.83 \\
June/2020 & 28.11 & 71.75 & 0 \\
July/2020 & 27.61 & 68.03 & 0 \\
August/2020 & 27.35 & 71.35 & 0 \\
September/2020 & 28.43 & 70.20 & 0 \\
\hline
\end{tabular}

Note: ${ }^{*}$ data processed from http://dataonline.bmkg.go.id/data_iklim, accessed 19/11/2020

In conclusion, based on the morphological characteristics of eggs, larvae, imago, and the damage symptoms, and subsequently, compared with the existing literature, it can be ascertained that the insect pests that attack maize plantations in East Flores were Spodoptera frugiperda. The damage caused by the S. frugiperda pest was highly severe, much heavier than the damage caused by other types of armyworms. Almost all maize fields (85 to 100 percent) have been attacked by FAW, most of which occurred in the early vegetative phase, making it challenging to recover. The damage intensity was classified as heavy with a scale ranging from 6 to 9. The larvae population per plant was high, ranging from 1 to 28 individuals plant ${ }^{-1}$ with an average of 6.65 larvae plant $^{-1}$ in West Solor sub-district, while in Ile Mandiri it ranged from 1 to 7 per plant with an average of 2.55 larvae plant $^{-1}$. Low rainfall and humidity, and high temperature are thought to be factors that influence population development and the intensity of damage caused by S. frugiperda. Rain intensity in Ile Mandiri subdistrict was more frequent than that in West Solor subdistrict; therefore, it is assumed that the rainfall factor plays an essential role in the development and damage caused by this FAW. Chemical control carried out on some fields was not effective because not all fields were uniformly sprayed with insecticides, and the insecticides used were not suitable for this FAW in maize.

\section{ACKNOWLEDGEMENTS}

This study was fully funded and supported by the University of Nusa Cendana, Kupang, Indonesia in 2020. Many thanks to Prof. Yosep Seran Mau and Prisca Deviani Pakan for contributing as proofreaders to improve this article.

\section{REFERENCES}

Assefa F, Ayalew D. 2019. Status and control measures of fall armyworm (Spodoptera frugiperda) infestations in maize fields in Ethiopia: A review. Cogent Food Agric 5 (1): 1-16. DOI: 10.1080/23311932.2019.1641902
Bagariang W. 2019. Identifikasi Hama Invasif Spodoptera frugiperda (JE Smith). Balai Besar Peramalan Organisme Pengganggu Tumbuhan, Indonesia. [Indonesian]

Baskauf SJ. 2003. Factors Influencing population dynamics of the southwestern corn borer (Lepidoptera: Crambidae): A reassessment. Environ Entomol 32 (5): 915-928. DOI: 10.1603/0046-225X32.5.915.

Brévault T, Ndiaye A, Badiane D, Bal AB, Sembène M, Silvie P, Haran J. 2018. First records of the fall armyworm, Spodoptera frugiperda (Lepidoptera: Noctuidae), in Senegal. Entomol Gen 37 (2): 129-142. DOI: 10.1127/entomologia/2018/0553.

BMKG. 2021. Data Online Pusat Data BMKG. https://dataonline.bmkg.go.id/home.

da Silva DM, Bueno A de F, Andrade K, Stecca C. dos S, Neves PMOJ, de Oliveira MCN. 2017. Biology and nutrition of Spodoptera frugiperda (Lepidoptera: Noctuidae) fed on different food sources. Scie Agric 74 (1): 18-31. DOI: 10.1590/1678-992x-2015-0160.

Du Plessis H, Schlemmer ML, Van den Berg J. 2020. The effect of temperature on the development of Spodoptera frugiperda (Lepidoptera: Noctuidae). Insects 11 (4): 1-11. DOI: 10.3390/insects11040228.

FAO \& CABI. 2019. Community-Based Fall Armyworm (Spodoptera frugiperda) Monitoring, Early Warning and Management Traing of Trainers Manual. Training of Trainers Manual First Edition. US AID from the American People. FAO, Rome.

Ganiger PC, Yeshwanth HM, Muralimohan K, Vinay N, Kumar ARV, Chandrashekara K. 2018. Occurrence of the new invasive pest, fall armyworm, Spodoptera frugiperda (J.E. Smith) (Lepidoptera: Noctuidae), in the maize fields of Karnataka, India. Curr Sci 115 (4): 621-623. DOI: /10.18520/cs/v115/i4/621-623.

Gutirrez-Moreno R, Mota-Sanchez D, Blanco CA, Whalon ME, TeránSantofimio H, Rodriguez-Maciel JC, Difonzo C. 2019. Field-evolved resistance of the fall armyworm (Lepidoptera: Noctuidae) to synthetic insecticides in Puerto Rico and Mexico. J Econ Entomol 112 (2): 792 802. DOI: $10.1093 /$ jee/toy372.

Harrison RD, Thierfelder C, Baudron F, Chinwada P, Midega C, Schaffner U, van den Berg J. 2019. Agro-ecological options for fall armyworm (Spodoptera frugiperda JE Smith)management: Providing low-cost, smallholder friendly solutions to an invasive pest. J Environ Manag 243, 318-330. DOI: 10.1016/j.jenvman.2019.05.011.

Hruska AJ. 2019. Fall armyworm (Spodoptera frugiperda) management by smallholders. CAB Rev 14 (43): 1-11. DOI: 10.1079/PAVSNNR201914043.

Jacobs A, Vuuren A. van, Rong IH. 2018. Characterisation of the fall armyworm (Spodoptera frugiperda J.E. Smith) (Lepidoptera: Noctuidae) from South Africa. Afr Entomol 26 (1): 45-49. DOI: 10.4001/003.026.0045

Jaramillo-Barrios CI, Barragán QE, Monje AB. 2019. Populations of Spodoptera frugiperda (Lepidoptera: Noctuidae) cause significant damage to genetically modified corn crops. Rev Fac Nac Agron Medellin 72 (3): 8953-8962. DOI: 10.15446/rfnam.v72n3.75730.

Jeger M, Bragard C, Caffier D, Candresse T, Chatzivassiliou E, DehnenSchmutz K, Gilioli G, Gregoire JC, Jaques MJA, Navarro MN, Niere B, Parnell S, Potting R, Rafoss T, Rossi V, Urek G, Van Bruggen A, Van der Werf W, West J, et al. 2017. Pest categorisation of Spodoptera frugiperda. EFSA J 15 (7): 1-32. DOI: 10.2903/j.efsa.2017.4927.

Maharani Y, Dewi VK, Puspasari LT, Rizkie L, Hidayat Y, Dono D. 2019. Cases of fall armyworm Spodoptera frugiperda J. E. Smith (Lepidoptera: Noctuidae) attack on maize in Bandung, Garut and Sumedang District, West Java. CROPSAVER - J Plant Protec 2 (1): 38-46. DOI: 10.24198/cropsaver.v2i1.23013.

Nboyine JA, Kusi F, Abudulai M, Badii BK, Zakaria M, Adu GB, Haruna A, Seidu A, Osei V, Alhassan S, Yahaya A. 2020. A new pest, Spodoptera frugiperda (J.E. Smith), in tropical Africa: Its seasonal dynamics and damage in maize fields in northern Ghana. Crop $\begin{array}{lllll}\text { Protection } 127 & \text { (September 2019): } 104960 . & \text { DOI: }\end{array}$ 10.1016/j.cropro.2019.104960.

Nonci N, Kalgutny, Hary S, Mirsam H, Muis A, Azrai M, Aqil M. 2019. Pengenalan fall armyworm (Spodoptera frugiperda J.E. Smith) hama baru pada tanaman jagung di Indonesia. Badan Penelitian dan Pengembangan Pertanian Balai Penelitian Tanaman Serealia. [Indonesian]

Nurzannah SE, Girsang SS, Girsang MA, Effendi R. 2020. Impact of climate change to fall armyworm attack on maize in Karo District, 
North Sumatera. IOP Conf Ser Earth Environ Sci 484 (1): 012111. DOI: $10.1088 / 1755-1315 / 484 / 1 / 012111$.

Prasanna B, Huesing JE, Eddy R, Peschke VM. 2018. Fall Armyworm in Africa: A Guide for Integrated Pest Management. In Mexico, CDMX: CIMMYT. (Vol. 1). www.maize.org.

Sisay B, Simiyu J, Mendesil E, Likhayo P, Ayalew G, Mohamed S, Subramanian S, Tefera T. 2019. Fall armyworm, Spodoptera frugiperda infestations in East Africa: Assessment of damage and parasitism. Insects 10 (7): 1-10. DOI: 10.3390/insects10070195.

Subiono T. 2020. Preferensi Spodoptera frugiperda ( Lepidoptera : Noctuidae ) pada Beberapa sumber Pakan (Preferences of Spodoptera frugiperda (Lepidoptera : Noctuidae ) in several feed sources ). Jurnal Groekoteknologi Tropika Lembab 2 (2): 130-134. DOI: 10.35941/JATL [Indonesian]

Sun XX, Hu CX, Jiang HR, Wu QL, Shen XJ, Zhao SY, Jiang YY, Wu KM. 2019. Case study on the first immigration of fall armyworm Spodoptera frugiperda invading into China. J Integr Agric 2019: 210. DOI: 10.1016/S2095-3119(19)62839-X.

Westbrook JK, Nagoshi RN, Meagher RL, Fleischer SJ, Jairam S. 2016. Modeling seasonal migration of fall armyworm moths. Intl J Biometeorol 60 (2): 255-267. DOI; 10.1007/s00484-015-1022-x. 